\title{
A loucura a dois $(1877)^{*}$
}

\author{
Drs. Ch. Lasègue e J. Falret
}

O alienado, por princípio, qualquer que seja a forma de sua doença, resiste com uma obstinação em si mesmo doentia a todos os argumentos que se possa colocar em contrário a seu delírio. A contradição o detém ou o deixa indiferente, mas ela em nada modifica o fundo de suas idéias. Intimidado ou já em vias da cura, ele consente, no máximo, em ficar calado, mas sua inteligência não se beneficia dessas reticências calculadas. Nessa relação, ele é comparável, em algum grau, às crianças que recuam diante da ameaça contra a expressão de seus sentimentos, porém esmerando-se em mostrar que não se engajam além de uma concessão aparente. Se a loucura não excluísse a persuasão, ela seria apenas um erro ao invés de ser uma doença.

Em compensação, o alienado não atua mais sobre as pessoas sadias de espírito, do que estas agem sobre ele. Foi dito que a alienação era contagiosa e que o convívio com os doentes não devia ser considerado isento de perigo para os que vivem em contato com eles. A coisa pode ser verdadeira para os que são predispostos à espera de uma oportunidade, mas é absolutamente falsa para a imensa maioria dos homens de bom senso. Os enfermeiros dos asilos não são mais expostos do que os dos hospitais,

1. Lasègue, C. \& Falret, J. La folie à deux. Annales Médico-Psychologiques, n. 18, p. 321355, 1877.

Tradução de Maria Vera Pacheco. Revisão técnica do Prof. Dr. Mário Eduardo Costa Pereira, Laboratório de Psicopatologia Fundamental - Unicamp. 
e a coabitação com os doentes não acarreta mais perigos para a família. Da mesma forma que não se consegue convencê-los, os loucos também não conseguem persuadir. Para que assim fosse, seria necessário que tivessem a seu serviço recursos morais e intelectuais incompatíveis com seu estado patológico; o proselitismo, quando se trata de idéias estranhas, as quais a razão é rejeita, não é uma obra fácil e ele só teria chance de sucesso se lhe fosse dispensada uma luta infatigável. Ora, o alienado vive à parte da opinião dos outros; ele basta a si mesmo e sua crença se impõe com uma autoridade tão irresistível, que pouco lhe importa que se queira ou não segui-lo no terreno do qual não se lhe destituirá.

Estabelece-se assim uma linha de demarcação absoluta que não admite compromisso.

Sua vida em comum com os outros alienados é nociva, e assim o é freqüentemente, mas não devido a um contágio do delírio. O assistente não se resigna de imediato em submeter-se ao fato consumado; ele espera que um esclarecimento possa permitir que a razão recobre seu poder e, seguro dessa confiança, ele empreende a educação do doente. O insucesso o irrita ou o desencoraja: ele esgota sua força de resistência e se cansa. Quando essa série de tentativas prolonga-se com as perplexidades que acarreta, as características vigorosamente arraigadas são as únicas que não sofrem sua inoportuna influência. Quanto mais estreitos são os laços que ligavam o assistente ao alienado, mais o zelo é ardente e o cansaço considerável. Por outro lado, os indiferentes escapam tanto a esse trabalho inutilmente doloroso quanto às suas conseqüências.

As coisas se passam assim, na suposição de um delírio absoluto, quando este ocorre diante de uma inteligência correta. Felizmente é a condição mais freqüente, mas existem casos em que a cisão entre o alienado e os que vivem em sua familiaridade não é tão formal e este estudo é consagrado a esses fatos excepcionais.

O problema compreende então dois termos, entre os quais trata-se de estabelecer uma equação: de um lado, o doente ativo, de outro, o indivíduo receptivo que sofre sua influência sob formas e graus diversos.

Sozinho, entregue a seus instintos patológicos, o alienado é relativamente fácil de ser examinado; ele tem gosto, até mesmo desejo de anunciar as idéias que o obsedam, ou ele decide-se por um mutismo sistemático, o qual não é menos significativo. Uma vez que se penetrou em uma praça, esta é tanto mais fácil de explorar, quanto menos for aberta ao mundo exterior.

As coisas se passam de forma bem diferente com seu cúmplice involuntário e inconsciente. Razoável apenas pela metade, raciocinando bastante, pronto a fazer sacrifícios provisórios às objeções, apto a tomar seu ponto de apoio fora das concepções delirantes que não criou, e às quais ele freqüentemente resistiu durante um longo período de tempo, ele escapa. Suas convicções, meio-mórbidas, meio-motivadas, estão longe de ter a base inabalável das concepções delirantes. 
$\begin{array}{lllllll}R & E & V & I & S & T & A\end{array}$

LATINOAMERICANA

DE PSICOPATO LOGIA

F U N D A M E N TA L

ano IX, n. 4, dez/2006

Há todo um trabalho de enquete psicológica para se discernir, em meio a esses elementos bastante confusos, a parte que resulta do contágio e aquela que pertence à natureza mental do confidente.

De um outro ponto de vista, o alienado sofre a pressão daquele que se associa às suas divagações, as encoraja, as coordena e as adapta mais ou menos à credibilidade. Para que essa solidariedade - da qual nenhum nem outro são conscientes - se estabeleça, é preciso uma convergência de circunstâncias da qual não é impossível dar-se conta.

A alienação brutal, fora das possibilidades, não solicita e não obterá jamais a adesão dos assistentes; em compensação, os delírios que se aproximam da verdade têm tanto mais chance de aquiescência, quanto melhor se acomodam a um sentimento, ou, como teriam dito os teólogos, mestres em casuística moral, quanto mais favorecem a concupiscência humana.

O alienado que afirma um fato notoriamente falso é acusado de impostura no mesmo instante. O objeto que ele observa não é visível àqueles que ele não consegue envolver na esfera de sua alucinação; a voz que ele escuta não é percebida; a perseguição organizada, tornada pública pelos jornais ou pelos escritos, não tem nem livros nem folhas periódicas a seu crédito. Nada tem a dizer pelo que um outro louco poderia ser seduzido; não tendo os alienados confirmados jamais desses tipos de docilidades e permanecendo mestres absolutos de seus delírios.

Se, ao contrário, o doente mantém-se no mundo das conjecturas e das interpretações, se os fatos que ele invoca pertencem ao passado, ou não são mais que apreensões para o futuro, o controle direto torna-se impossível. Como provar a um outro e a si mesmo que o acontecimento, cujos detalhes o alienado conta com uma prolixidade persuasiva, não aconteceu? A lição que ele ensinou a si mesmo não admite nem variações, nem lacunas; sua memória é tópica porque faz exceção de tudo, exceto as idéias doentias. Em qualquer data à qual remonte a aventura, ele jamais é pego em falha, e sua persuasão, por força de ser monótona e circunscrita, torna-se comunicativa.

O assistente, contudo, não consente em deixar-se convencer, a menos que a história o interesse pessoalmente; ora, os dois sentimentos que melhor se prestam a essa maneira de arrebatamento são, com certeza, o temor e a esperança. Um e outro buscam um ponto de partida nas realidades presentes; o verdadeiro domínio deles está no futuro, e partindo para o desconhecido. Tanto é fácil para um homem adquirir a certeza que você não é rico, quanto lhe é penoso garantir que você não o será. O legislador, definindo a trapaça, impõe uma penalidade a qualquer um que "seja fazendo uso de nomes falsos ou de qualidades falsas, seja usando manobras fraudulentas para persuadir a existência de falsos empreendimentos, de um poder ou de um crédito imaginário, para fazer nascer 
a esperança ou o temor de um sucesso, de um acidente ou de qualquer outro acontecimento quimérico (...) terá espoliado ou tentado espoliar a totalidade ou parte da fortuna do próximo”. Se suprimirmos todos os epítetos que impliquem uma responsabilidade da parte do delinqüente, teremos a fórmula dos delírios que encontram aderentes.

A conformidade de idéias responde à conformidade de sentimentos, todas as vezes que se trate de algo possível e que a razão não se revolte. Ora, os alienados, cujas concepções delirantes se consomem em previsões inquietantes ou consoladoras, são, em suma, os que mais se aproximam do estado fisiológico.

Seria possível, por meio de graduações imperceptíveis, marcar a passagem desde as simples disposições de traços até a loucura, começando por pessoas temerosas ou propensas a infatigáveis esperanças, e chegar aos alienados aterrorizados, aos melancólicos absorvidos por uma apreensão incessante, ou aos ambiciosos esperando satisfações sempre próximas. Essa forma de aspiração delirante não desperta, então, uma repulsão e, em graus medianos, convoca menos a negação que a dúvida. Quantas vezes o médico, mesmo experiente, não se pergunta se a entrada nesse estado não foi um acidente real, ao invés de ser um acontecimento quimérico, e hesita entre um exagero e uma aberração sentimental?

No delírio a dois, o alienado, agente provocador, responde efetivamente ao tipo do qual acabamos de esboçar os principais traços. Seu associado é mais delicado para ser definido, mas com uma pesquisa perseverante, consegue-se acompanhar as leis que são obedecidas por este segundo fator da loucura comunicada.

A primeira condição é que ele seja de uma inteligência fraca, mais disposta à docilidade passiva do que à emancipação; a segunda, que ele viva em relação constante com o doente; a terceira, que ele esteja engajado pelo estímulo de um interesse pessoal. Não se sucumbe à fraude a não ser pela sedução de um lucro, qualquer que seja. Não se cede à pressão da loucura a não ser que ela o faça entrever a realização de um sonho acalentado.

Nós consideraremos sucessivamente cada um desses dados a partir das informações fornecidas pela observação.

$1^{\circ}$ ) As crianças, apreensivas por natureza, confinadas num meio sem expansão, são essencialmente dispostas a tornar-se ecos de um delírio ao qual são associadas. Seu raciocínio indeciso não opõe resistência e, por menos que o alienado as tenha incluído, elas esperam ou temem por conta própria, com o egoísmo inerente à sua idade. Sua fé, em alguns casos vai tão longe que o próprio alienado hesita em segui-los e à primeira vista se acreditaria que as crianças criaram os delírios dos quais são o reflexo. Em geral, e salvo em exceções muito raras, as concepções assim transmitidas são mais aterrorizadoras do que agradáveis. Sabe-se o quanto as crianças predispostas às perturbações cerebrais são acessíveis ao temor. 
As manifestações espontâneas consistem em terrores na hora do sono, temores no escuro, sonhos em pesadelo, medos de perigos imaginários ou de indivíduos ameaçadores. As manifestações provocadas artificialmente movem-se na mesma esfera. As alegrias do futuro pouco os tocam; é somente mais tarde que aparecem as aspirações invejosas para o prazer, a fortuna etc., quando a previsão fica melhor embasada pelo desenvolvimento da razão, e que não se desenvolvem absolutamente a não ser vários anos depois da eclosão da puberdade, quando a criança está bem perto de ser um adulto.

Duas senhoras solteiras aceitaram, como única herança de uma de suas irmãs, uma pequena órfã, magra, pálida, com a idade de oito anos. A vida é difícil e os recursos abaixo das necessidades. Uma das irmãs morre e com a falta dos rendimentos de seu trabalho, a existência é ainda mais apertada: a outra irmã é tomada por um delírio de perseguição banal, na forma senil. Os vizinhos uniramse contra ela, vozes a injuriam, barulhos aos quais ela atribui um sentido ameaçador, se produzem. A alienação avança num progresso lento e, ao final de quatro anos tomou tais proporções que os moradores da casa se inquietam.

A criança, que sai apenas para tarefas urgentes, é questionada enquanto sua tia recusa-se a deixar o quarto, onde fica fechada. Sabe-se pela menina que pessoas maldosas tentaram envenená-la, assim como à sua tia; todas as duas tiveram graves acidentes, inimigos entraram durante a noite para arrancá-la da proteção de sua parenta. Ela responde a todas as questões com a lucidez das crianças cuja coabitação com idosos fez amadurecerem antes do tempo. Suas asserções são muito mais plausíveis na medida em que representam a loucura da doente ausente, atenuada, aparada pela sobrinha que não é uma alienada.

Acontece então um fato curioso que vimos se reproduzir várias vezes. As concepções delirantes, reduzidas à sua mais fraca expressão passando pelo crivo de uma inteligência meio-sadia, são mais próximas da razão do que qualquer outra idéia engendrada no cérebro de um alienado. Os auditores têm menos aversão em aquiescer; as objeções que eles levantaram foram acolhidas; a criança renunciou a algumas de suas enunciações, das quais lhe foi mostrada a impossibilidade; as que restam têm ainda mais valor. A experiência é como a regra já colocada que: quanto menos o delírio é brutal, mais se torna comunicável.

Os vizinhos tomam a defesa da criança, apelam por ela à autoridade, imaginando uma fábula romanesca cuja natureza justifique essas pretensas perseguições. A enquete e o exame, efetuado por um de nós, não deixa subsistir nenhuma dúvida. A doente é internada em um asilo e a criança num orfanato onde ela se cura dessa doença, por assim dizer, parasitária; mas as pessoas do bairro ainda conservam suspeitas e não se declaram satisfeitas.

Em outros casos, a participação da vizinhança é mais ativa; ela não apenas acolhe, mas provoca as confidências e, passando de boca a boca, o relato se 
retifica ou se amplifica. A criança encontra-se então entre duas correntes. Uma, a do alienado, que foi o promotor de suas concepções, e outra, a dos assistentes, que atenuam as incoerências e completam os aspectos admissíveis, ao sabor de suas paixões. Desviado por uns, endireitado pelos outros, a criança acaba por acreditar e, em seguida, por fazer com que acreditem em suas invenções de segunda mão.

Essa dupla cultura era muito marcada num fato que mencionaremos, sem entrar em detalhes interessantes, mas que seria muito extenso relembrar. Tratase ainda de uma jovem, nesse caso criada por sua mãe, que o pai deixou na miséria para fugir não se sabe para onde. A mãe é perseguida, mas seu delírio, sem complicações de senilidade (ela tem quarenta anos), refere-se a objetos definidos. São os padres, sobretudo um deles, que estão obstinados contra ela e a impedem de encontrar trabalho. A filha tem 16 anos e apresenta abscessos, é anêmica, de dimensões e estatura médias e inteligência pouco desenvolvida. Aprendeu a ler somente com um grande esforço, freqüentou pouco a escola e não se comprometeu com nenhuma aprendizagem. A mãe e a filha vivem com economia, partilhando a pequena pensão que lhes oferece um parente em melhores condições financeiras. Elas moram no mesmo quarto, dormem na mesma cama e não se distanciam nunca uma da outra. A criança repete para os vizinhos as proposições delirantes de sua mãe; afirma com ela que um padre de tempos em tempos vem visitá-las à noite quando está deitada e que as luzes estão apagadas e que ele as ameaça. Sua mãe o escuta, apesar dele falar em voz baixa e ela também, mas de forma confusa. De manhã, sua mãe repete para ela tudo o que ele disse e ela lembra-se bem de tê-lo escutado.

Os confidentes comunicam entre si os detalhes dessa estranha aventura e acrescentam seus comentários. Agrada-lhes descobrir que esse padre imaginário não gosta da virtude da menina e eles desta o persuadem facilmente. A partir daí, queixa, exame médico e constatação da loucura caracterizada da mãe.

Nesses dois fatos, como em todos os outros que nos foram dados observar (e são bastante numerosos), a loucura nasceu no adulto e disseminou-se na criança; constituiu-se de um delírio de perseguição com muita apreensão.

Citaremos apenas uma breve observação e, no lugar de uma exposição do caso, daremos, por assim dizer, a estenografia do relato ao qual as duas doentes estão associadas. O fato referido dessa maneira é cru e quase brutal, mas por isso torna-se surpreendente e dá, por assim dizer, a nota característica da situação.

A mulher M... tem 35 anos e sua filha tem 13. O delírio banal data de cerca de quatro meses e a mãe foi submetida a um exame médico em virtude da queixa dos vizinhos. Ela é de estatura média, emagrecida, pálida e quase febril; fisicamente ela reclama de náuseas freqüentes, de insônia, de cansaços sem doença. Perturbações gástricas bastante freqüentes são atribuídas por ela a 
$\begin{array}{lllllll}R & E & V & I & S & T & A\end{array}$

LATINOAMERICANA

DE PSICOPATO LOGIA

F U N D A M E N TA L

ano IX, n. 4, dez/2006

tentativas repetidas de envenenamento. Ela sente na boca como um gosto de açafrão, que a embrutece e a irrita, aliás, ela encontrou açafrão em seus alimentos.

"Isso começou”, diz ela, “quando me seguiam nas ruas; os vizinhos intrometeram-se e me insultaram. Evidentemente, existem pessoas que me são estranhas e outras que eu conheço; é claro que existe uma espécie de complô. Há algumas semanas fazem vigília em minha porta. Há oito dias, eu fugi de casa no meio da noite, para ir dormir na casa de uma amiga. Lá também bateram no portão e tentaram levantá-lo com alavancas; eu escutei.

Eu não fiquei lá e quis voltar para casa, mas tive que fugir e pedir para dormir na casa de outra senhora. Lá não aconteceu nada.

Voltei para casa; tentaram abrir a porta durante minha ausência, trocaram minha chave. Vários objetos desapareceram do meu quarto, faixas de lã de merinos, lãs, seda etc.

É durante a noite que me atormentam e vão embora às 7 horas da manhã. Eu os escutei remexendo e fiz uma barricada com minha cama, mas eu não os escuto falar.

As pessoas que me perseguem são V... e S..., meus vizinhos. V... disse diante de mim: sempre tem isso e aquilo. Sua mulher fez correr o boato de que todas as noites eu ia entregar minha filha para comer.

Não sei por que não gostam de mim; minhas mobílias não devem despertar inveja; é pura maldade. Rasgaram minha roupa na igreja, me injuriando; eu tinha ido levar minha filha e não conhecia ninguém.

Esgotada, dormindo somente de manhã, eu tinha resolvido levar minha filha para a consulta do hospital. Desci às duas horas da madrugada, do alto de minha casa, que tem mais de um andar, por uma escada, carregando minha filha nas costas; não sei como não nos matamos. Eu passeei com a criança durante toda a noite e pela manhã, dispensaram-nos da consulta. Eu tenho meu sogro em Paris que aceitaria com prazer nos receber, mas tenho medo por ele porque ele estava sozinho. Como estão me perseguindo, persiriam a ele também”.

A menina M.., 13 anos, é delgada e aparenta menos idade; está vestida com uma roupa suja e em farrapos; suas respostas são entrecortadas de soluços. Eu gostaria de ver minha mãezinha; quando mamãe saía para trabalhar tinha um homem que por debaixo da porta fazia hou! hou!, como o vento; eu tinha medo, não tinha coragem de me deitar, eu estava doente. Durante a noite faziam medo à mamãe também. Era um homem que tirava seus tamancos; não o ouvíamos andar e ele chegava sob a porta. De manhã, ao meio dia, à noite, eu pensava que havia pessoas escondidas debaixo da cama. Ouvia-se como se alguém levantasse os móveis e a porta; nós éramos obrigadas a fazer uma barricada com a cama. Escutamos pancadas durante a noite; arrancaram um pedaço da porta com uma 
alavanca. Eu escutei antes de mamãe, mas não ousei lhe dizer. Eu nunca vi nada, mas escutei bem que andavam e que esfregavam papéis no ladrilho.

Mamãe me contou que era uma mulher que não gostava dela.

Desses relatos sumários apresentados, um representa o delírio de perseguição clássico, o outro exprime apenas terrores infantis e uma credulidade, explicados pela idade da criança. É preciso lembrar que a doença da mãe é recente, que a filha foi associada apenas às manifestações mais grosseiras e, no entanto, sua afirmação não deixou de ter influência. Por um lado, ela garantia a autenticidade das alucinações auditivas; por outro, ela incitava a mãe a atos que ela sozinha talvez não tivesse arriscado. Ainda no início da loucura, a mulher M. preocupa-se com as conseqüências que uma coabitação perigosa teria para seu sogro; ela preocupa-se com uma ansiedade mais ativa com a sorte reservada à sua filha e vimos como tinha tentado poupá-la dos perseguidores. Ora, nessas loucuras de tipo psíquico, ser solicitado a agir é acelerar a progressão das concepções delirantes.

$2^{\circ}$ ) As coisas não acontecem assim quando a transmissão ocorre inversamente de um sujeito jovem para um indivíduo senil, ou apenas mais velho e de inteligência fraca. $O$ adulto reflete mais passivamente; na aparência ele também é convencido, também afirmativo, mas não exagera e nem desenvolve as concepções delirantes, pela falta de um esforço de imaginação que lhe seria custoso. Poder-se-ia dizer que se trata menos de uma persuasão real do que de um assentimento que se anuncia por frases exclamativas: Ah! É verdade; não há que se duvidar, ela não mente etc.

Quando a associação delirante se estabelece entre adultos, o estado mental do receptor é mais complexo. A criança obedecia aos instintos de sua idade, enquanto o adulto substituiu os impulsos instintivos por hábitos, cálculos, combinações nas quais pressente o forte e o fraco. Coloca-se como advogado de sua própria causa e só se entrega na medida em que isso lhe parece estar de acordo com seus interesses. No entanto, a criança mente e a obstinação de sua mentira acaba por conduzir à verdade. $\mathrm{O}$ adulto engana quando lhe convém e sabe calar as razões íntimas que o fazem agir.

Entretanto, por se tratar de inteligências debilitadas, é possível descartar o que é falso e descobrir a realidade escondida sob artifícios bastante banais, em parte por meio de intimidação e em parte por persuasão. Percebe-se então que os adultos e as crianças aproximam-se por surpreendentes analogias e é por essa razão que insistimos a respeito dos delírios infantis reflexos.

Existe, no entanto, diferenças que são menos devidas aos procedimentos intelectuais do que da liberação de uma obrigação. Todo indivíduo amadurece pela experiência da vida e, por mais fraco que se suponha que seja, guarda noções das misérias que sofreu, ou das quais ouviu falar. Paralelamente, guarda o desejo das alegrias que experimentou ou que conhece apenas por ouvir dizer. Todo homem 
$\begin{array}{lllllll}R & E & V & I & S & T & A\end{array}$

LATINOAMERICANA

DE PSICOPATO LOGIA

F U N D A M E N TA L

ano IX, n. 4, dez/2006

tem, como se diz, um romance completo em sua cabeça. Portanto, para seduzilo, é preciso que a concepção da fantasia em comum corresponda às suas preocupações do momento, e essa necessidade de uma comunhão de sentimentos entre o alienado e seu associado se realize facilmente na vida.

Da parte dos desconhecidos, muitas manifestações, mesmo vulgares, nos surpreendem. As pessoas com as quais formamos o hábito de viver no comércio de cada dia podem, ao contrário, se permitir extravagâncias que não nos afligem e não nos espantam, acostumados que somos a seu humor. Existe uma espécie de adaptação para as relações sociais que atenua o imprevisto, se não o suprimir.

A coabitação constante de um indivíduo fraco com um alienado, sem remissões e sem reticências, a participação das mesmas esperanças e dos mesmos temores, mesmo solicitada por acontecimentos dos quais uma parte não deixa de ter ligações com a realidade, organizam a transição entre a razão enfraquecida e o delírio. Aliás, a loucura no meio que nós representamos não ocorre por uma invasão súbita. O período prodrômico preparou casualmente os meios. Os dois confidentes confrontaram (viveram em comum) suas aspirações e suas dores e, quando um dos dois vem a exceder o limite do razoável, o outro não o transpõe bruscamente, mas o penetra por uma insinuação progressiva. É, portanto, pouco a pouco que se efetua esse trabalho de solidariedade.

Entregue a si próprio, mesmo que seja durante algumas horas por dia ou alguns dias por semana, o neófito do delírio reflete, dúvidas o assaltam, a razão se restabelece. Para que a conversão seja completa é preciso um treinamento sem tréguas, que não lhe deixa tempo para refazer-se.

Efetivamente, esse é o caso dos delirantes a dois. As relações sempre foram estreitas e prolongadas durante muito tempo; o segundo doente está sempre misturado com o começo da doença tendo percorrido suas sucessivas fases. Lutando de início, defendendo-se cada vez menos, intervindo, enfim, nas concepções que vai lentamente assimilando. Essa degradação é evidente em todas as observações, e ela é tanto mais manifesta quanto se puder penetrar mais adiante na evolução íntima da doença.

Deve-se, portanto, colocar em primeira linha os elementos essenciais que acabamos de resumir: primeiramente, a modelação relativa do delírio, seus lados sentimentais, sua concordância com as disposições daqueles que se adaptam a ele; em segundo lugar, a repetição incessante dos mesmos propósitos, renovados sem remissão; e enfim, a debilidade intelectual e moral do participante.

Uma vez que o contrato tácito que vai ligar os dois doentes foi quase concluído, não se trata apenas de examinar a influência do alienado sobre o homem supostamente sadio de espírito, mas trata-se de buscar a ação inversa daquele que raciocina sobre o delirante, e de mostrar por quais tipos de compromissos mútuos efetuam-se as divergências. 
Que se tente colocar um louco acometido de manias de perseguição levadas ao extremo, alucinado, egoísta em excesso, implacável em suas observações obstinadas, insensível tanto à aprovação como à dúvida, em relação com qualquer tipo de homem dotado da melhor determinação, nada sairá dessa associação a não ser o cansaço. O semiperseguido, que estende sua solicitude doentia sobre os que o rodeiam, confundindo-os consigo em suas apreensões e aguçando suas inquietudes algo confusas com um pouco de esperança, não se mantém indiferente à resistência ou ao encorajamento do auditor. Este repete, com variações, a lição que lhe foi ensinada; ele desbasta, por assim dizer, os absurdos exageradamente brutais; ele preenche as lacunas excessivas com dados quase lógicos. Pouco a pouco a história destaca-se e sistematiza-se, analisada e consideravelmente refeita.

$\mathrm{O}$ alienado aproveitou, não de uma educação à qual ele permanece fatalmente insensível, mas contraiu o hábito de um relato tantas vezes reproduzido, que não exige mais esforço.

Todos os médicos sabem com que estranha fixação de memória certos perseguidos contam suas aventuras imaginárias, não esquecendo nem um detalhe, nem uma data, nem um incidente. Não é a história inventada, mas formulada a dois, que eles contam.

Dessa assídua colaboração resulta uma tal homogeneidade no dizer dos doentes, que freqüentemente é preciso um longo tempo, duplicado por uma ativa pesquisa, para discernir o delirante primitivo do secundário. É quando um foi separado do outro durante vários dias, quando não apenas a vida em comum foi rompida, mas quando o meio tenha sido transformado, que adquire-se uma certeza. O dado psicológico mais curioso não é o que nos fornece a influência do alienado sobre o indivíduo de espírito sadio: pelo contrário, é a ação que exerce o confidente sensato sobre o alienado. A experiência verdadeira que representa o alienado como fechado a qualquer persuasão, tão incapaz de ser desviado por uma objeção quanto de aceitar um acréscimo em suas idéias favoritas, não se desmente.

Estudando o trabalho insidioso que é executado no espírito do doente, rapidamente percebe-se que ele não cedeu nem um dedo de seu terreno. Suas aparentes concessões limitaram-se em ficar calado provisoriamente, ou em deixar na sombra algumas de suas idéias patológicas. Os loucos em vias de cura, ou no primeiro período ainda incerto da doença, prestam-se voluntariamente a semelhantes reticências; e essa é uma das dificuldades bem conhecidas do exame.

Se considerarmos especificamente o doente primitivo e se nos dermos ao trabalho de estudá-lo atentamente, acabamos por romper o gelo e sob a superfície encontrarmos a forma e a tenacidade das concepções delirantes, exatamente como são observadas nos doentes isolados. Muitas vezes essa investigação incisiva é difícil, mas raramente, se se atua com paciência, não se tem êxito. 
$\begin{array}{lllllll}R & E & V & I & S & T & A\end{array}$

Em que medida consegue-se destruir esse paralelismo, se isolarmos os dois pacientes ao invés de confrontá-los lado a lado, quase sempre falando ao mesmo tempo, ou no mínimo repetindo as mesmas idéias com as mesmas frases, entendendo-se sem o apoio do olhar, tal como crianças que recitam em uníssono um verso decorado?

É através desse estudo comparativo que se pode estimar o grau de penetração da doença adquirida e convencer-se com facilidade de que a designação de contágio não é a mais conveniente à situação respectiva dos dois indivíduos. O doente real permanece sendo o doente, enquanto o alienado, por reflexo, não conseguiu ultrapassar os limites do absurdo.

Ora, por mais longe que o absurdo seja levado, tem em comum com a loucura apenas as grosseiras aparências. Ela é móvel, caprichosa, compatível com certos poderes de razão e não obedece às leis que se impõem à toda alienação. Pela força da perseverança as crenças equivocadas, que pareciam tão firmemente embasadas, são abaladas; o erro tem momentos de indecisão, e se não aceitamos nos confessar vencidos, muitas vezes discernimos a ponta de amor próprio ou de respeito humano ali atravessadamente colocada.

$\mathrm{O}$ alienado que se resigna a declarar que renuncia a seus pensamentos delirantes comete uma mentira que lhe custa caro. O indivíduo dominado por opiniões absurdas com as quais persiste obstinadamente, comete na maioria das vezes uma mentira, mas no sentido inverso. O contraste é suficiente para estabelecer a mais intransponível linha de demarcação entre os dois: um é louco, no sentido social e médico da palavra, o outro não o é.

Para o falso doente, a adesão das pessoas ao seu redor representa um auxílio considerável. Como ele aceitou as idéias que lhe foram sugeridas, admitem-se as que ele enuncia com algumas reservas, e ele vai buscar novas forças nesse apoio tácito ou explícito. Colocado diante de uma contradição persistente e dominado pela vontade de um interlocutor que faz quase a função de juiz, ele perde pouco a pouco sua segurança. O verdadeiro doente não está mais a seu lado para sustentá-lo, e se tomamos o cuidado de atenuar suas contradições, ao invés de fazê-las aflorar, ele experimenta uma espécie de alívio por ser liberado de suas concepções parasitárias.

Indicamos os principais pontos dos quais deve tratar o estudo dos doentes delirantes a dois. Não nos esqueçamos que se trata de uma das formas da alienação, intermediárias entre a razão e a loucura confirmada, e que, isentas de perturbações físicas caracterizadas, prestam-se apenas a uma análise psicológica.

As observações que vamos ler, e que escolhemos visando apresentar os diversos tipos, emprestam um aspecto bastante particular à natureza da doença, e se parecem mais com estudos de comportamentos do que com observações 
médicas. Não poderia ser diferente quando a pesquisa implica um duplo exame: o do doente e o do indivíduo sadio entrando na corrente das divagações. As aventuras reais da vida, a organização do meio onde esses acontecimentos ocorrem, têm um papel importante na evolução dos delírios atenuados, e o relato composto de dados verdadeiros, de crenças interessadas, de invenções delirantes, de esforços sinceros colocados a serviço das divagações, não se ajusta às formas científicas.

O primeiro fato que relatamos resume tão bem as condições pelas quais nasce e se desenvolve o delírio a dois, que podemos considerá-lo exemplo de um dos tipos desses casos.

A pessoa chamada X..., 66 anos, exerce a profissão de parteira numa cidade do interior. Sua inteligência foi rebaixada antes da idade e sua clientela baixou paralelamente. Seus recursos de economia eram apenas suficientes às necessidades da mulher $\mathrm{X}$ e de sua filha que vivia às suas expensas; o marido havia desaparecido há muito tempo.

Um último golpe veio completar a miséria; o modesto emprego de parteira ligado ao serviço de beneficência, ou a uma Sociedade de caridade, é tirado da doente. Durante cinco anos ela vive de suas economias, apertando ainda mais os estreitos laços que a unem à sua filha.

Esta tem 28 anos; é de estatura média, bastante viva de espírito, mas no fundo de uma inteligência limitada. Ela seguiu alguns estudos e inclusive obteve o diploma de professora de segundo grau, sem conseguir utilizar quaisquer de seus conhecimentos. Por diversas vezes teve oportunidade de obter uma colocação na França ou no estrangeiro; por razões que ela formula de maneira bastante confusa, nenhuma dessas tentativas foi alcançada.

Assim, a pobreza crescente chega a seu auge. As duas mulheres são expulsas de seu modesto domicílio, sem recursos e, ao que parece, mais incômodas do que interessantes aos olhos de suas raras relações. Faz-se uma pequena coleta em favor delas, da qual a municipalidade local participa, e que monta a 40 francos. Com esse pecúlio, são enviadas à Paris onde, lhes dizem, têm todas as chances de ganhar a vida.

Elas desembarcam na cidade, completamente estranhas, num pequeno hotel onde são recebidas com benevolência.

Para que essas duas provincianas tenham consentido numa tal viagem, para que se tenha sonhado em lhes propor essa solução, seria necessário que esse deslocamento absurdo respondesse a alguma coisa além da banal confiança na hospitalidade de uma grande cidade.

De fato, a moça X... tinha um propósito, ao qual associou sua mãe. Existe em algum lugar uma sucessão Dubois, ou, como diz a mãe (traduzindo em sua linguagem as afirmações de sua filha), um por receber que vem dos Dubois. 
$\begin{array}{lllllll}R & E & V & I & S & T & A\end{array}$

LATINOAMERICANA

DE PSICOPATO LOGIA

F U N D A M E N TA L

ano IX, n. 4, dez/2006

Ignora-se a proveniência e a soma dessa herança, mas sabe-se que é significativa. Um parente, irmão de uma, tio da outra, devia ser herdeiro, sem que se pudesse adivinhar a que título, pois ele não porta o nome do pretenso testador, mas ele tinha, por assim dizer, juntado os papéis e tomado as providências que com sua morte foram interrompidas.

A invenção é, como se vê, bastante popular. De tempos em tempos circulam histórias de imensas fortunas acumuladas fantasticamente, e que esperam por um feliz desconhecido destinado a recebê-las, desde que tenha justificado seus direitos. Geralmente o defunto tem um nome comum bastante propagado, que suscita numerosos pretendentes.

Para resolver-se a aspirar uma situação tão invejável e converter em convicção imutável, um sonho que excede todas as fantasias, é preciso um trabalho intelectual do qual só os alienados são capazes.

Aqui, após um prolongado exame, consegue-se seguir os trâmites das concepções delirantes, imaginados pela moça, e refletidos pela mãe que lhe dá a contribuição de sua confirmação, a autoridade de sua idade, a sobriedade do relatório e essa aparência de sinceridade dos relatos romanescos reproduzidos em segunda mão.

Sendo o parente um policial aposentado, foi dito após sua morte que ele havia feito um testamento. Ora, por que havia ele feito o testamento se não tinha um tostão para doar? Deve ter sido lacrado judicialmente e nunca se comunicou a documentação. É porque havia um interesse em roubá-las.

A primeira concepção do delírio remonta hoje há dois anos (o irmão morreu há cinco anos) e, uma vez estabelecido dessa forma, divide-se e segue duas direções: de um lado, afirmar o direito à herança, de outro, procurar saber por quais manobras subterrâneas as verdadeiras destinatárias foram despojadas.

A primeira tarefa parece, por um compromisso tácito, ter sido reservada principalmente para a mãe; a segunda, a que consiste em despistar a perseguição, destina-se à filha mais imaginativa.

Um nascido $\mathrm{R}, \ldots$ cuja individualidade permanece bastante incerta, mas que elas supõem ligada a um seminário, lhes fez dizer por uma mulher que não podia ser o mandatário de um outro indivíduo: vá conhecer. Essa frase enigmática, tão conforme com aquelas que repetem as alucinações auditivas, foi a primeira revelação falada; conversa-se sobre ela, comenta-se a dois sobre ela e depois de um ano de reflexão inquieta, decide-se seguir sobre esse início.

Um M.C... homem de negócios, que o parente herdeiro presumido conheceu, deve ser encarregado da sucessão, na qual eles são três para dividir: as duas doentes, uma de suas parentes ainda viva e o nascido R...

A mãe, incitada pela filha, dirige-se à casa de M.C...; pede-lhe para adiantar o dinheiro ou confiar-lhe um título sobre o qual ela possa fazer provisoriamente 
um empréstimo. Este recusa, coloca a mulher para fora, declarando não saber de que negócio se tratava. No entanto, ele disse a uma mulher: é verdade, e a uma outra que elas deveriam ocupar-se de seus assuntos.

A moça escreve cartas e mais cartas a M.C..., mas não recebe resposta e esse silêncio, que ela não ousa romper com uma nova visita, torna-se um argumento a mais em favor da base sólida de suas pretensões.

É nessa ocasião que acontece a viagem a Paris. Como dissemos, as duas mulheres desembarcam numa casa mobiliada mantida por uma senhora X... Procuram trabalho e não encontram. Oferecem à moça um lugar de professora na Polônia; ela o recusa porque sua ausência prejudicaria o sucesso do empreendimento.

A dona do hotel parece ter, em alguma medida, sofrido a influência desse delírio, que talvez tivesse se tornado uma alienação a três se as relações tivessem sido mais estreitas e mais duráveis. Entretanto, elas limitam-se cada vez mais a expedientes, vende-se o pouco que se possui, um anel, roupas de casa. A bagagem acaba por reduzir-se à posse de algumas roupas usadas.

Dividida entre piedade e confiança num futuro melhor, a senhora X... adianta pouco a pouco alguns francos; a dívida cresce rapidamente e chega a quase 100 francos, pois nenhuma das despesas de aluguel ou de alimentação é paga.

Por que a dona do hotel foi tão favorável, por que ela emprestou seu próprio dinheiro? Não se corre riscos semelhantes quando não se tem razões para fazêlo. É porque ela tomou informações, já que sabia da herança proximamente realizável. Aliás, ela deixou que se ouvisse isso por palavras equivocadas. A quem faremos acreditar que isso ocorre em Paris, sem que seja em função de presentes?

Sendo prolongado o mutismo de M.C..., escreve-se ao notário, que não mais responde pois nada mais tem a responder a respeito de um patrimônio imaginário para ser dividido entre herdeiros de fantasia. A má vontade tomou as proporções de um complô, e aí começa o papel predominante da moça.

R... é seminarista, ou suposto como tal, pois nem uma e nem outra o viram; elas sabem apenas que ele conhecia seu parente, o colecionador de papéis autênticos. Ora, uma igreja foi construída na cidade onde o seminário da diocese está instalado. Diz-se que essa igreja custou 5.000 francos. Quem fez a doação dessa soma considerável? Evidentemente, R..., que deve ter herdado em primeiro lugar, visto que foi ele que deixou subentender a existência da herança. O notário disse a uma pessoa: “Essa mulher que me escreve é doente”. É que ele jurou nada revelar.

“O clero está implicado nesse negócio, a herança existe, mas eu fui alijada dela por culpa dos padres, diz a filha. Comenta-se em toda parte que o arcebispo quer que abandonemos nossa parte. Mamãe não prestou atenção nisso, mas eu estou certa de havê-lo escutado. Aliás, não se inventa esse tipo de coisas”. 


\section{$\begin{array}{lllllll}R & E & V & I & S & T & A\end{array}$ \\ LATINOAMERICANA \\ DE PSICOPATO LOGIA \\ F U N D A M E N TA L \\ ano IX, n. 4, dez/2006}

Uma vez que a perseguição é admitida, afirma-se mais a cada passo e podese compreender como é fácil sucumbir à idéia de uma perseguição, quando todo esforço é impotente, todo recurso esgotado, e que, segundo a expressão da mãe, nada mais resta a não ser morrer de fome.

A parte proporcional de cada doente é mal revelada num relato condensado, mas fica clara para quem conduz a enquete e dirige o interrogatório. A mãe, que tem o papel secundário, tem dificuldade para encontrar-se na rede de deduções lógicas, com a ajuda da qual a perseguição é provada e explicada. O tema, sem as variações, é suficiente e ultrapassa o limiar de sua inteligência. A filha, pelo contrário, se compraz com o relato do complô onde ela reata os fios, com menos habilidade, no entanto, do que muitos outros doentes com delírios persecutórios.

Esporadicamente ela, como os espíritos de segunda ordem, apela a um desses aforismos usados de bom grado como premissas para suas argumentações: "Eu procurei trabalho, mas recusaram-me. Por que? Eu apresentei currículos e não os olharam. É somente a malevolência organizada que pode ser a causa de tudo isso".

Quanto à existência de uma verdadeira alienação, nenhum médico experiente a colocará em dúvida. Ela é provada, menos pelo absurdo dos primeiros fundamentos, do que pelo mecanismo intelectual, com a ajuda do qual foi desenvolvida. Em resumo, tudo baseia-se sobre um não-senso; não existe nem herança e nem paridade de nomes com a pessoa que legou o testamento, Dubois, nem elementos, nem papéis para que sirvam de apoio.

Proposições indiretas, palavras desprovidas de sentido servem de pontos de partida ou de ponto de apoio; como em toda loucura, é a fé mórbida que comanda, não admitindo nem objeção e nem controle.

A associação das duas doentes, das quais uma delira apenas por encargo, apenas suavizou os ângulos, limitou o delírio numa sistematização conveniente, e que pode impô-la a alguns fracos de espírito.

(Após a exposição desse caso típico, o texto de Lasègue e Falret continua). 